\title{
Modeling Height-Diameter Relationship and Volume of Teak (Tectona grandis L. F.) in Central Lowlands of Nepal
}

\author{
A. Koirala ${ }^{* 1}$, A. R. Kizha ${ }^{1}$ and S. Baral ${ }^{2}$ \\ ${ }^{1}$ School of Forest Resources, University of Maine, Orono, USA \\ ${ }^{2}$ Institute of Forestry, Tribhuvan University, Nepal
}

Date Received: 18-12-2016

Date Accepted: 06-04-2017

\begin{abstract}
Forests have played a vital role in the socio-economic development of Nepal with their productive, protective, and bio-esthetic functions. Stand height-diameter as well as volume estimation is very critical in forest management. This research modelled height-diameter relationship as well as tree volume for Teak (Tectona grandis), a well-known tropical hardwood species, in central lowland Nepal. Data was collected from a Teak plantation site in Sagarnath Forest Development Project (SFDP), Nepal. Forty-four trees representing different diameter classes were felled. The diameter at breast height (dbh) and height $(\mathrm{H})$ of the trees ranged from 6.1 to $58.9 \mathrm{~cm}$ and 6.1 to $26.1 \mathrm{~m}$, respectively. Several height-diameter models were fitted and evaluated for certain training and validating criteria. The height-diameter equation of $H=[-5.2544+(6.8603 \times \ln (d b h))]$, performed well and was selected to be the best model for $\mathrm{H}$ prediction from dbh. Also, the volume equation of $V=[0.3364+(0.0685 \times d b h)+(-0.097 \times H)]$ was selected as best fitted equation, using dbh and height as independent variables. The height in this volume equation was to be calculated from selected height-diameter equation to predict height. The equations developed are the first of their kinds officially documented for Teak species in central lowlands of Nepal.
\end{abstract}

Keywords: Allometric Equation, Diameter Class, Hardwood Species, Plantation, Tropical Forest.

\section{Introduction}

Teak (Tectona grandis L.f.) is a very important and valuable multipurpose tropical hardwood tree species of south and south-east Asia. The natural distribution of the species ranges from India to Burma, Laos and Thailand (Hansen et al., 2015). Teak plantations have been set up in large scale throughout the world both within and out of its natural distribution. At present, teak is one of the major planted tree species in Indonesia, tropical African countries like Nigeria, Ghana and Ivory Coast, South and Central American countries like Panama, Costa Rica, Brazil and others (Tewari and Mariswamy, 2013). It has been widely used for furniture, ship building, carved-wood products and residential constructions. The strength, durability, and ease of working without cracks are some properties that make teak so popular among the regions for forestry plantations. In Nepal, the government initiated teak plantations in Chiliya of Rupandehi district in 1960 followed by a large-scale plantation in Sagarnath Forestry Development Project (SFDP), Sarlahi district and Ratuwamai Project, Jhapa district (Thapa and Gautam, 2005). In SFDP, teak forms a major component of the plantations, (Eucalyptus comaldulens is being the next); and has been able to meet almost half of the demand for teak within the nation.

*Correspondence: anil.koirala@maine.edu

Tel: +12078897154

ISSN 2235-9370 Print / ISSN 2235-9362 Online @2017 University of Sri Jayewardenepura 
Teak is a tropical deciduous tree species, belonging to the family-Verbenaceae and order-Laminales. Teak is naturally found in a wide range of climatic conditions and its natural habitat spans approximately 27.9 million ha. The species grows well in the regions having rainfall and temperature ranging from $900-2,500 \mathrm{~mm}$ and $17^{\circ}-43^{\circ} \mathrm{C}$, respectively (Die et al., 2012). Soils also vary from acidic to fertile alluvial. Such huge variation in growing conditions can result in diversity within the growth features and other tree characters such as form, mode of branching, flowering pattern and wood quality. For example, the mean annual volume increment (MAI) of teak plantations can range from 2 to $>15 \mathrm{~m}^{3} \cdot \mathrm{ha}^{-1}$. The MAI of natural stands ranges from $2-8 \mathrm{~m}^{3} \cdot \mathrm{ha}^{-1}$ and for plantation this rate could potentially be doubled due to artificial fertilization and irrigation (Zahabu et al., 2015). Furthermore, the rotation age can vary from 20 years in fertile plantations up to 40-80 years in state held plantation. Stump planting is the most common form of tree propagation. However, dibbling of seeds and tissue-cultured plants have also been practiced in the past (Kaosa-ard, 1998).

\subsection{Height-diameter and volume models}

Height $(\mathrm{H})$ and diameter at breast height $(\mathrm{dbh})$ are the most important measures of tree growth and their relationship is useful in determining site-index, calculating tree volume, evaluating site-quality and predicting future growth of the stand (Jayaraman and Zakrzewski, 2001; Wagle and Sharma, 2012). These equations can also help in predicting $\mathrm{H}$ from $\mathrm{dbh}$, as $\mathrm{Hs}$ are often sub-sampled due to the difficulty in measurement (Coble and Lee, 2011). Various models describing the height-diameter relationship of different tree species have been modelled in the past (Lappi, 1997; Trincado and Burkhart, 2006; Sharma and Parton, 2007; Budhathoki et al., 2008; Coble and Lee, 2011).

Despite the increasing use of biomass and density, volume is the most widely used traditional measure for tree quantity. In forest management, tree heights and dbh have been used to estimate the total and merchantable tree volume. These parameters are preferred due to the ease of acquiring data and the relative accuracy provided by methods employing them. Volume models that are able to quantify tree volume are necessary if trees are subjected to fell for commercial uses (Mugasha et al., 2016). They are also employed to forecast volumes of other stands having similar conditions. There have been many developments of volume equations since the chronological development of forest measurements and this trend has highly increased after development of computers and sophisticated data analysis mechanisms (Weiskittel et al., 2011).

Although, more than 300 volume and height-diameter equations have been developed in South Asia till 2014 (Sandeep et al., 2014), no such volume equations for teak in Nepal have been documented (Thapa and Gautam, 2007). In SFDP, volume equations for Eucalyptus species were prepared about a decade ago. Hence, this study has made an attempt to create a suitable height-diameter equation as well as localized and generic volume equations for teak in the central lowland, Nepal. The results can be used by district foresters as well as private land owners to make sound decision for better management of teak plantation.

\section{Materials and Methods}

\subsection{Study Area}

Due to legal restrictions to cut large number of teak trees in Nepal, Sagarnath was the only site within central lowland of the nation which could support research activities of this scale. The field study was carried out at a teak plantation site of SFDP in Sarlahi district, Nepal during the summer of 2014 (Figure 1). The total area of the project is 13,512 ha, of which plantations comprised of 11,796 ha; natural forest-395 ha; protected forest-706 ha; and water bodies-615 ha. The project has engineered massive plantation of Teak and Eucalyptus since its establishment in 1980s (Mandal et al., 2013). 
The lowland forest of Nepal, characterized as "Terai-Duar Savannas and Grasslands" eco-region, has an estimated volume of 68.91 million $\mathrm{m}^{3}$, with around 240 million trees $(\geq 5 \mathrm{~cm}, \mathrm{dbh})$ and stand density of 583.40 trees $\cdot \mathrm{ha}^{-1}$ (FRA/DFRS, 2014). The major forest type in the region comprised of mixed hardwood tropical forest with the dominant species being Shorea robusta G. f. $\left(91.72 \mathrm{~m}^{3} \cdot \mathrm{ha}^{-1}\right)$. The lowland region of Nepal extends from $80^{\circ} 4^{\prime} 30^{\prime \prime}$ to $88^{\circ} 10^{\prime} 19^{\prime \prime}$ east longitudes; and from $26^{\circ} 21^{\prime} 53^{\prime \prime}$ to $29^{\circ} 7^{\prime} 43^{\prime \prime}$ north latitude. The elevation ranges from 60 to $330 \mathrm{~m}$ above mean sea level and the region has a gentle slope. This region of Nepal is characterized by hot summers ( $35^{\circ}$ to $45^{\circ} \mathrm{C}$ in April/May) with excess down pouring and dry winters $\left(10^{\circ}\right.$ to $15^{\circ} \mathrm{C}$ in January). The average annual rainfall is from 1,130 to $2,680 \mathrm{~mm}$ (FRA/DFRS, 2014).
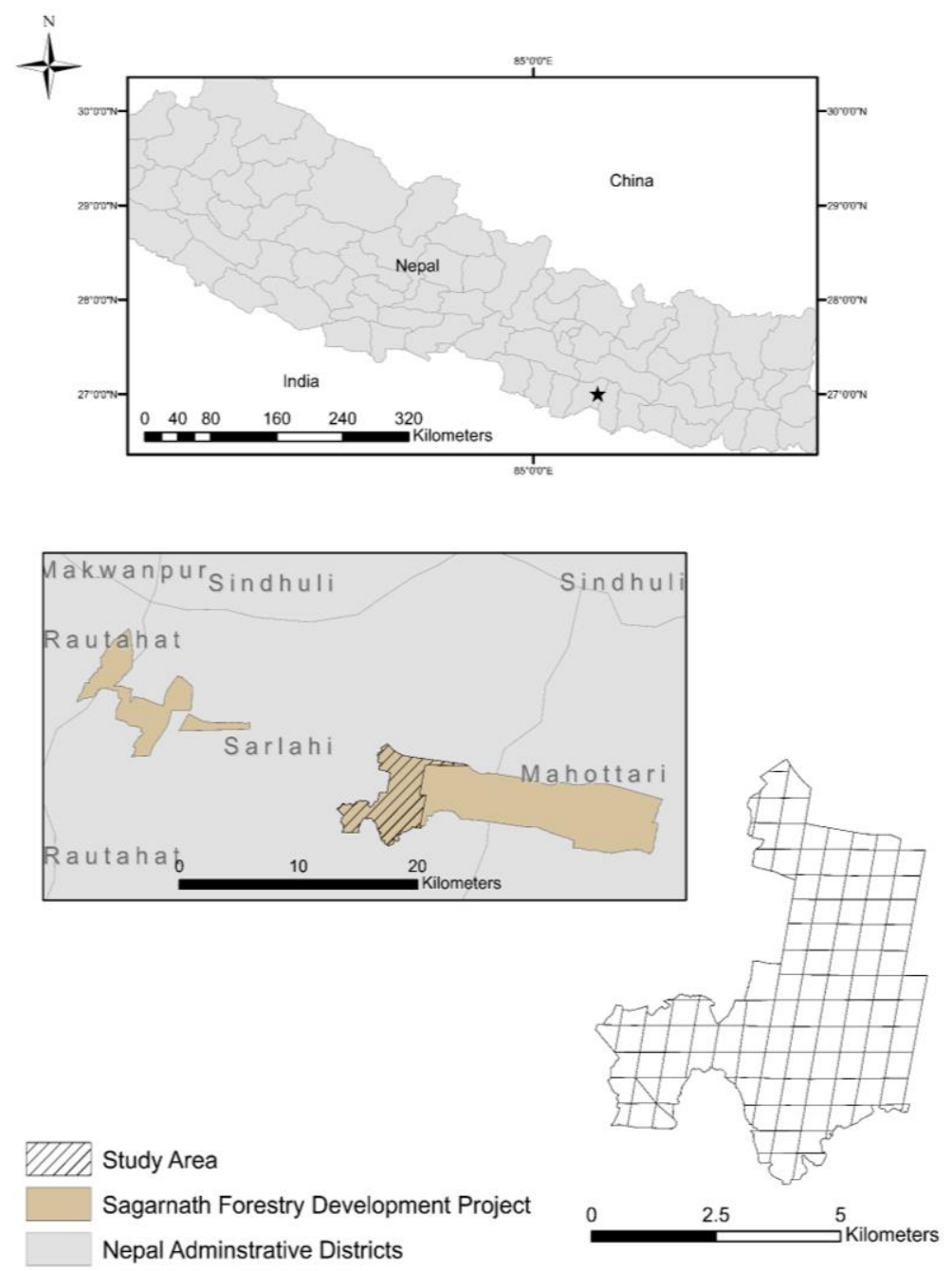

Figure 1: The location of the study site in Sagarnath Forestry Development Project, Nepal.

\subsection{Data}

Twelve sub-compartments (stands) from the study sites spanning over a total of 100 ha were selected for conducting this research. A preliminary inventory analysis was carried out to examine the variation in $\mathrm{H}, \mathrm{dbh}$, and volume of trees for the study sites. The average tree density and dbh for the sub-compartments were 344 trees $\cdot \mathrm{ha}^{-1}$ and $35 \mathrm{~cm}$, respectively. The number of samples was then determined ensuring that it represented the whole forest, and all size variation within each sub-compartment. Forty-four trees without observable defects and abnormalities were randomly 30 
selected for destructive sampling. Candidate trees excluded those that were open grown, edge of the sub-compartment, and diseased. The dbh of trees were measured at the height of $1.3 \mathrm{~m}$, before felling. All branches were removed from the main stem (bole) and the total length of the main stem was measured. The height of the stump was set at $0.10 \mathrm{~m}$ from ground level for all trees felled. Total length of the felled tree added with tree top height gave total tree height. Stump height was not added for volume estimation. Number of trees sampled in different dbh and height classes is presented in Table 1.

Table 1: Distribution of felled trees according to the diameter at breast height and height class

\begin{tabular}{|c|c|c|c|c|c|c|c|}
\hline \multicolumn{8}{|l|}{ Height (m) } \\
\hline & & $5-10$ & $10-15$ & $15-20$ & $20-25$ & $25-30$ & Total \\
\hline \multirow{7}{*}{$\begin{array}{l}\text { Diameter at } \\
\text { breast } \\
\text { height }(\mathrm{cm})\end{array}$} & $0-10$ & 6 & 2 & & & & 8 \\
\hline & $10-20$ & 1 & 7 & 1 & & & 9 \\
\hline & $20-30$ & & 3 & 5 & & & 8 \\
\hline & $30-40$ & & 1 & 2 & 3 & 1 & 7 \\
\hline & $40-50$ & & & 3 & 3 & & 6 \\
\hline & $50-60$ & & & & 6 & & 6 \\
\hline & Total & 7 & 13 & 11 & 12 & 1 & 44 \\
\hline
\end{tabular}

Felled trees were then cut to $3 \mathrm{~m}$ logs lengths, depending upon the height of the individual tree. Diameters (at top, middle and bottom) and length of each section were measured. Volume of each log section was calculated using Newton's equation (equation 1), as it was regarded more representative compared to Huber's and Smalian's equations (Husch et al., 2002). Tree tops were considered as cones and the volume was calculated using respective equation (equation 2 ):

$$
\begin{aligned}
& V_{\text {log }}=\frac{\left(A_{B}+4 A_{M}+A_{T}\right) * L}{6} \\
& V_{\text {tree top }}=\pi \times r^{2} \times L / 3
\end{aligned}
$$

Where, $\mathrm{V}_{\log }$ and $\mathrm{V}_{\text {tree top}}-$ volume of $\log$ section and tree top, respectively; $\mathrm{A}_{\mathrm{B}}$ basal area at the bottom of the log section; $\mathrm{A}_{\mathrm{M}}$ - basal area at the middle; $\mathrm{A}_{\mathrm{T}}-$ basal area at the top; $\mathrm{r}$-bottom radius of tree top; and L-length of the log section/ tree top.

Total stem volume of a single tree was the sum of volume for all sections and tree top, excluding stump. Out of 44 trees, 31 (70 \% of the data) were randomly selected to build the model, while 13 trees (remaining $30 \%$ ) were set aside for analyzing the performance of the model.

\subsection{Statistical Analysis}

Before developing the volumetric model and establishing height-diameter relations, scatter plots were used to check whether the relationships between transformed independent and dependent variables 
were linear. For the training data set, the goodness of fit statistics for models such as significance of parameter estimates, coefficient of determination $\mathrm{R}^{2}$, and standard error were assessed. Different transformation models were developed and compared; however, natural logarithmic transformed models were selected (Parresol, 1999). The logarithmic transformation equalized the variance over the entire range of volume component and satisfied the assumptions of linear regression (Spruge, 1983; Basuki et al., 2009; Kizha and Han, 2016). Multi-collinearity was tested using a tolerance value greater than 0.1 and variance inflation factor less than 10 .

Models were also subject to validation after training. There are different approaches for model's validation. The first one is the re-sampling technique in which the model developed is fitted on to a new set of independent data (Bi and Hamilton, 1998). Another approach would be the use of two independent data sets representing the same area, one set can be used for training and the other for validation. A similar technique was employed in this study by dividing the data collected into two random groups of certain percentages, which was adopted for this study. Validation was mainly carried out to test the predictive capacity of the models. For this, the difference between observed and predicted values was also considered. The best-fitted models on both stages i.e. training and validation were selected for predicting $\mathrm{H}$ from $\mathrm{dbh}$, and volume from $\mathrm{dbh}$ or $\mathrm{dbh}$ and $\mathrm{H}$. The models were tested using ordinary least square and non-linear least procedure from nlstools package in R (Baty and Delignette-Muller, 2015; R Core Team, 2016). Four criteria were evaluated during model validation procedure (Table 2).

Table 2: Criteria used for validating candidate models

\begin{tabular}{lll}
\hline Criterion & Equation & Ideal result \\
\hline AIC & AIC $=f(\beta)+2 p$ & Smaller AIC value \\
Adjusted $\mathrm{R}^{2}$ & adj. $R^{2}=1-\frac{(n-1)}{(n-p) \frac{\sum_{i=1}^{n}\left(x_{i}-\hat{x}_{i}\right)^{2}}{\sum_{i=1}^{m}\left(x_{i}-\bar{x}_{i}\right)^{2}}}$ & Higher adj. $\mathrm{R}^{2}$, ideal value is 1 \\
RMSE & RMSE $=\sqrt{\frac{\sum_{i=1}^{n}\left(x_{i}-\hat{x}_{i}\right)^{2}}{n}}$ & Smaller RMSE value; ideal \\
Bias & Bias $=\frac{\sum_{i=1}^{n}\left(x_{i}-\hat{x}_{i}\right)}{n}$ & value is 0 \\
\end{tabular}

$f(\beta)$-negative of the marginal log-likelihood function; $\beta$-vector of parameter estimate; $\mathrm{p}$-number of parameters used in the model; n-total non-missing observations; $x_{i}$-observed height or volume; $\hat{x}_{\hat{i}}$-predicted height or volume from model; and $\bar{x}$-average height or volume of the observed data.

\section{Results and Discussion}

\subsection{Summary of Tree Data}

The summary statistics of tree data (Table 3 ) showed that mean dbh for training data set was $27.91 \mathrm{~cm}$, while it was $27.85 \mathrm{~cm}$ for validation data. The maximum height of the teak tree in whole data was $26.10 \mathrm{~m}$. Although the data was grouped into two sets the average statistics of both sets had no significant difference for all three variables $(\mathrm{p}<0.05)$. 
Table 3: Summary statistics of the data divided into two different sets

\begin{tabular}{cclll}
\hline Variable & Mean & $\begin{array}{l}\text { Standard } \\
\text { deviation }\end{array}$ & Minimum & Maximum \\
\hline $\begin{array}{c}\text { Training data set } \\
\text { dbh (cm) }\end{array}$ & 27.91 & 16.03 & 6.37 & 58.92 \\
H (m) & 16.13 & 5.21 & 5.70 & 26.10 \\
Tree volume $\left(\mathrm{m}^{3}\right)$ & 0.65 & 0.64 & 0.01 & 2.13 \\
Validation data set & & & 6.05 & 57.32 \\
dbh (cm) & 27.85 & 18.70 & 6.10 & 23.30 \\
H (m) & 16.08 & 5.66 & 0.01 & 2.44 \\
Tree volume $\left(\mathrm{m}^{3}\right)$ & 0.76 & 0.92 & & \\
\hline
\end{tabular}

$\mathrm{dbh}$ - diameter at breast height; and $\mathrm{H}$ - height of the tree excluding stump height

\subsection{Height-diameter Relationships}

The initial observation of the scatter plot diagram of $\mathrm{H}$ against dbh for all 44 trees showed a non-linear relationship existing between them (Figure 2). Previous models developed for tree species in different parts of the world also showed similar trends (Calama and Montero, 2004; Sharma and Yin Zhang, 2004; Sharma and Parton, 2007; Sharma, 2009).

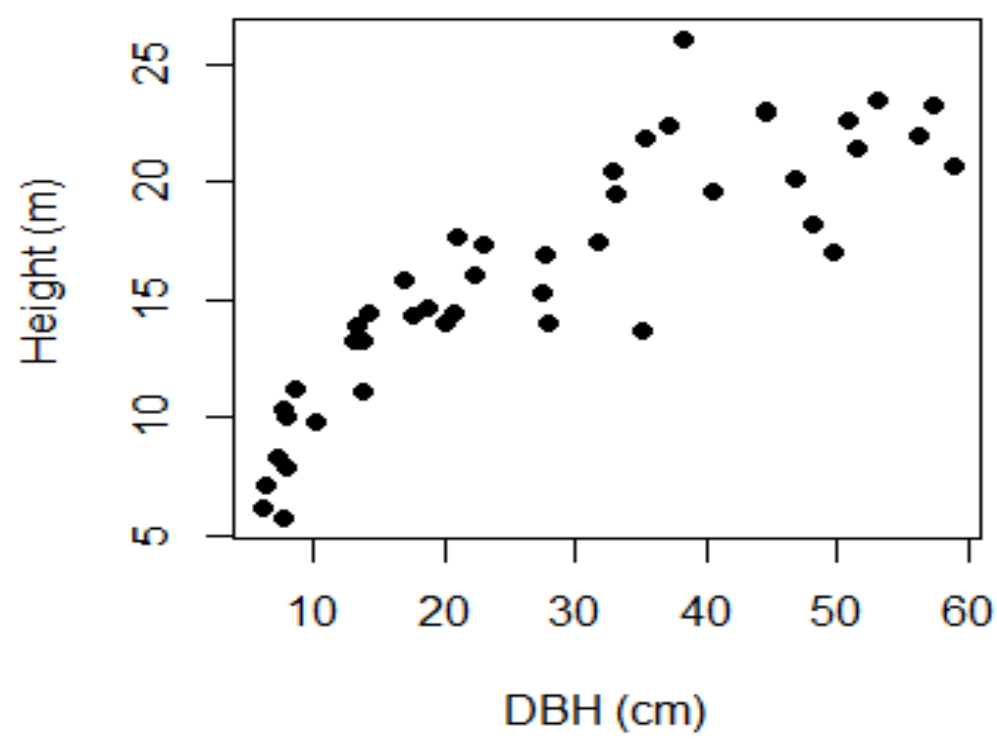

Figure 2: Scatter plot showing height $(\mathrm{m})$, of the trees against diameter at breast height, $\mathrm{dbh}(\mathrm{cm})$. 
The nonlinear models were developed having $\mathrm{dbh}$ as the independent variable and $\mathrm{H}$ as dependent variable. Model $\mathrm{H} 1$ incorporated $\mathrm{dbh}$ and squared value of $\mathrm{dbh}$ as independent variables; whereas $\mathrm{H} 2$ included a single independent variable of natural logarithm of dbh. Model H3 used dbh and natural logarithm of squared value of dbh as independent variables; while two independent variables - natural logarithm of dbh and squared value of dbh were used in model H4 (Table 4).

Table 4: Candidate height-diameter models used in the study

\begin{tabular}{ll}
\hline \multicolumn{1}{c}{ Height-diameter Models } & Model Designation \\
\hline$H=a+b \times d b h+c(d b h)^{2}$ & $\mathrm{H} 1$ \\
$H=a+b \times \ln (d b h)$ & $\mathrm{H} 2$ \\
$H=a+b \times d b h+c \times \ln (d b h)^{2}$ & $\mathrm{H} 3$ \\
$H=a+b \times \ln (d b h)+c(d b h)^{2}$ & $\mathrm{H} 4$ \\
\hline
\end{tabular}

In the height-diameter models, $H$ is total height of tree excluding stump height; $d b h$ is diameter at breast height at $1.3 \mathrm{~m}$. height above ground; $a, b$ and $c$ are parameters to be estimated; $\ln (d b h)$ and $\ln (d b h)^{2}$ are natural logarithm of diameter at breast height and its squared value respectively; and $\mathrm{H} 1$, $\mathrm{H} 2, \mathrm{H} 3$ and $\mathrm{H} 4$ are the candidate height-diameter models.

Table 5: Final statistics of data set for height-diameter models

\begin{tabular}{ccccccccc}
\hline Models & Parameter & $\begin{array}{c}\text { Parameter } \\
\text { estimate }\end{array}$ & $\begin{array}{c}\text { Standard } \\
\text { Error }\end{array}$ & $\mathrm{R}^{2}$ & Adj. ${ }^{2}$ & RMSE & Bias & AIC \\
\hline $\mathrm{H} 1$ & $\mathrm{a}^{1}$ & 4.1607 & 1.182 & 0.907 & 0.888 & 1.66 & $<0.0001$ & 58.06 \\
& $\mathrm{~b}^{1}$ & 0.6704 & 0.093 & & & & & \\
& $\mathrm{c}^{1}$ & -0.0064 & 0.002 & & & & & \\
$\mathrm{H} 2$ & $\mathrm{a}^{1}$ & -5.2544 & 1.488 & 0.928 & 0.921 & 1.46 & $<0.0001$ & $52.72^{*}$ \\
& $\mathrm{~b}^{1}$ & 6.8603 & 0.466 & & & & & \\
$\mathrm{H} 3$ & $\mathrm{a}^{1}$ & -7.1423 & 3.417 & 0.928 & 0.914 & 1.46 & $<0.0001$ & 54.72 \\
& $\mathrm{~b}$ & -0.0441 & 0.072 & & & & & \\
& $\mathrm{c}^{1}$ & 3.9305 & 0.847 & & & & & \\
$\mathrm{H} 4$ & $\mathrm{a}^{1}$ & -6.5730 & 2.518 & 0.928 & 0.914 & 1.45 & $<0.0001$ & 54.71 \\
& $\mathrm{~b}^{1}$ & 7.4303 & 0.993 & & & & & \\
& $\mathrm{c}$ & -0.0004 & 0.001 & & & & & \\
\hline
\end{tabular}

${ }^{1}$ Significant parameters at $\mathrm{p}=0.05$; and $*$ Lowest AIC value

The goodness of fit statistics was obtained for the four height-diameter models. All parameter estimates of models $\mathrm{H} 1$ and $\mathrm{H} 2$ were significant at $95 \%$ confidence level (Table 4 ). The $\mathrm{R}^{2}$ values of all four models were comparatively higher (from 0.907 to 0.928 ). Except H1, more than $91 \%$ of height variability were described by all three models (adjusted $\mathrm{R}^{2}>0.91$ ). Validation of the models for height was carried out using 30\% validation data set. Comparing the root mean square error RMSE, model H4 gave the lowest value of 1.45 followed by models H3, H2 and H1 (Table 5). As the bias percent for the validating data set were very low, it was not regarded for factoring the best model. Comparing the AIC 
values, model $\mathrm{H} 2$ showed least value of 52.72. Based on the given four criteria and significance of parameter estimates, model $\mathrm{H} 2$ was regarded as best model for height estimation from dbh.

To find out best model, all models were again analyzed from graphical examination of residual plots (Figure 3) and predicted heights laid over observed heights (Figure 4). The results from residual plot analysis showed model $\mathrm{H} 2$ performed well compared to other models (Figure 3b). The analysis of observed and predicted heights showed that in model $\mathrm{H} 1$ heights started decreasing when dbhs were higher than $55 \mathrm{~cm}$ (Figure 4a). Except than model H1, all remaining three models showed similar trends of height increment. However, model $\mathrm{H} 2$ was considered best fitted in graphical analysis. Hence, with lowest AIC value and all significant values of parameter estimates, model $\mathrm{H} 2$, that has natural logarithm of dbh as independent variable, was considered best height-diameter equation for height estimation from given dbh of teak trees in central lowland, Nepal.

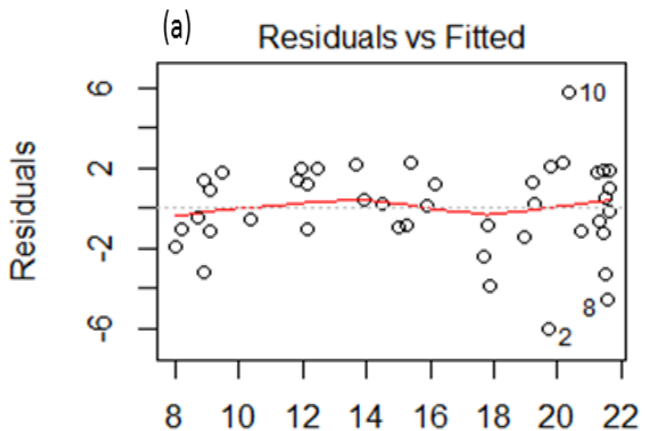

Fitted values

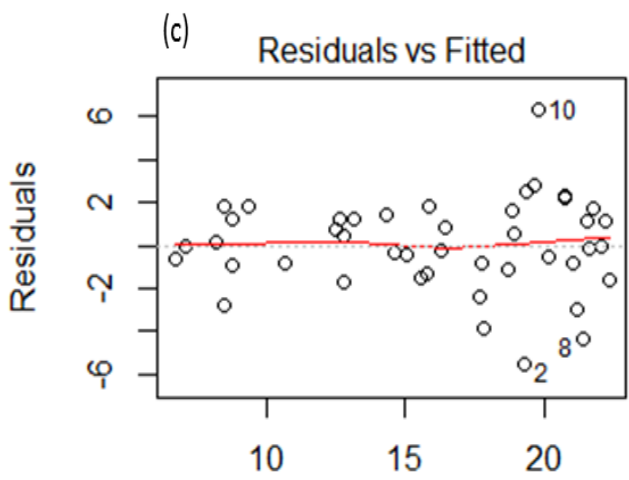

Fitted values

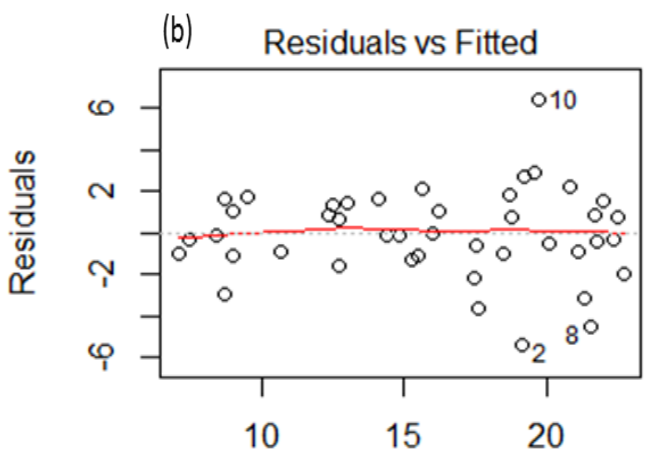

Fitted values

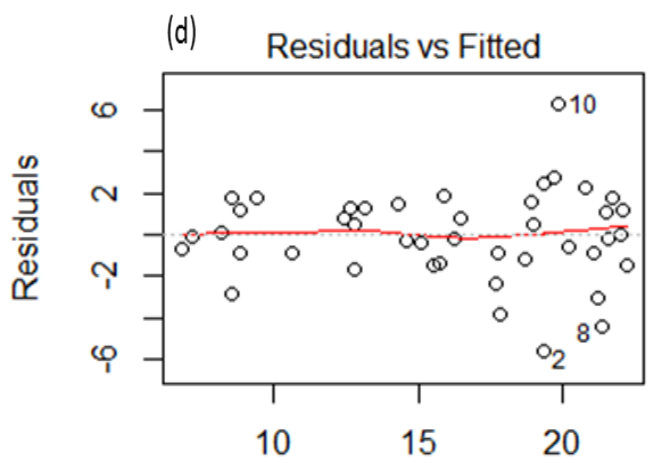

Fitted values

Figure 3: (a), (b), (c) and (d). Residual plots of models $\mathrm{H} 1, \mathrm{H} 2, \mathrm{H} 3$ and $\mathrm{H} 4$ respectively, showing residuals at $\mathrm{Y}$-axis and fitted values at $\mathrm{X}$-axis. 

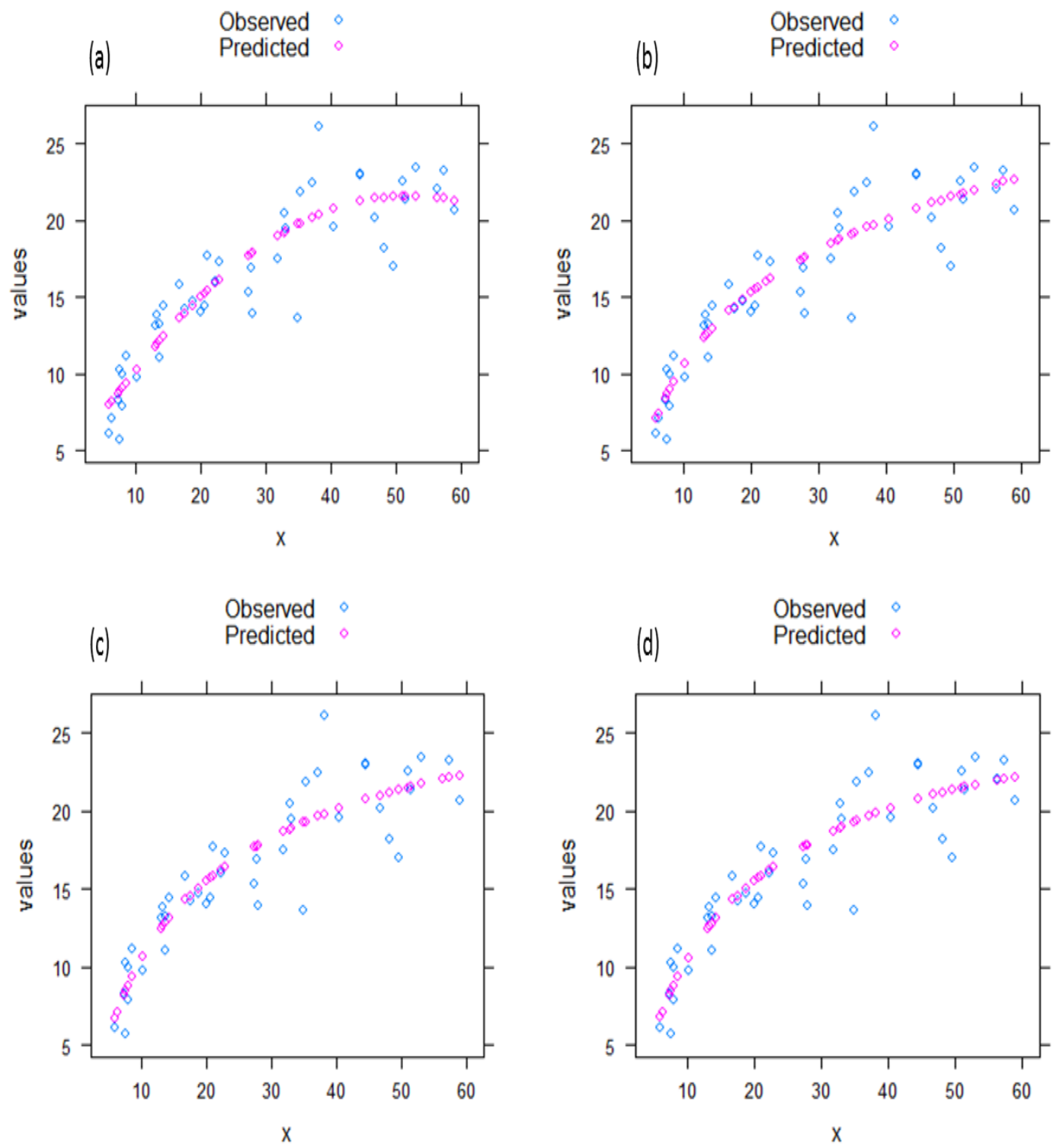

Figure 4: (a), (b), (c) and (d). Scatter plots of height and dbh (diameter at breast height) showing observed heights and predicted heights from candidate models $\mathrm{H} 1, \mathrm{H} 2, \mathrm{H} 3$ and $\mathrm{H} 4$ respectively. Diameter at breast height $(\mathrm{dbh})$ is represented by $\mathrm{x}$, at $\mathrm{X}$-axis and the values at $\mathrm{Y}$-axis indicate observed or predicted heights.

The selected height-diameter equation i.e. model $\mathrm{H} 2$ was compared with two famous height-diameter equations: (a) Weibull equation (cited in (Zeide, 1993)); and (b) Chapman (1961) (Chapman, 1961); and Richards (1959) (Richards, 1959) (cited in (Peng et al., 2001)). The observed versus predicted plot was prepared from the height-diameter equations (Figure 5). The graphical analysis showed that the prediction of height from model $\mathrm{H} 2$ was similar to that of Chapman and Weibull models for dbh up to 60 $\mathrm{cm}$. However, it overestimated the height of tree above $60 \mathrm{~cm}$ dbh range (Figure 5). Although, there were no trees above $60 \mathrm{~cm}$ dbh in sample data, some trees above that range were observed in the study area. 


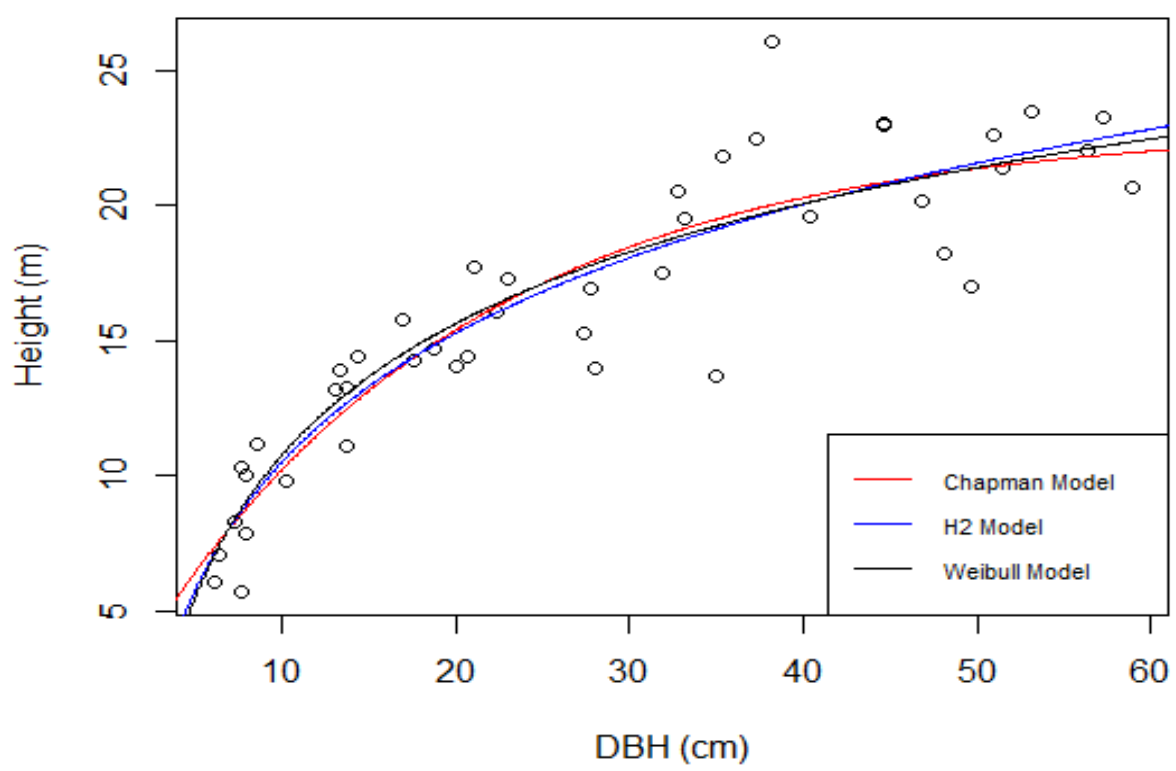

Figure 5: Graph of teak model (denoted by blue line) compared with Chapman (Chapman, 1961) and Richards (Richards, 1959) (denoted by red line), and Weibull (cited in (Peng et al., 2001)) (denoted by black line) models for predicting total height of the teak trees in meter ( Y-axis) against $\mathrm{dbh}$ (diameter at breast height) in $\mathrm{cm}$ (X-axis).

\subsection{Volume Equation}

In volume models, total volume of the bole (stem) can be predicted using dbh only or using both $\mathrm{dbh}$ and $\mathrm{H}$. Tree form is also often used for volume prediction along with former two variables. However, tree forms were not accounted for this study. Based on the observation from scatter plot diagrams between volume and dbh, as well as volume and $\mathrm{H}$ (Figure 6), several volume models were created. For the selection, the models that were previously developed for different species including teak in different regions were reviewed (Cordero and Kanninen, 2003; Gautam and Thapa, 2007; Perez, 2008; Tewari et al., 2013; Chaturvedi and Raghubanshi, 2015).

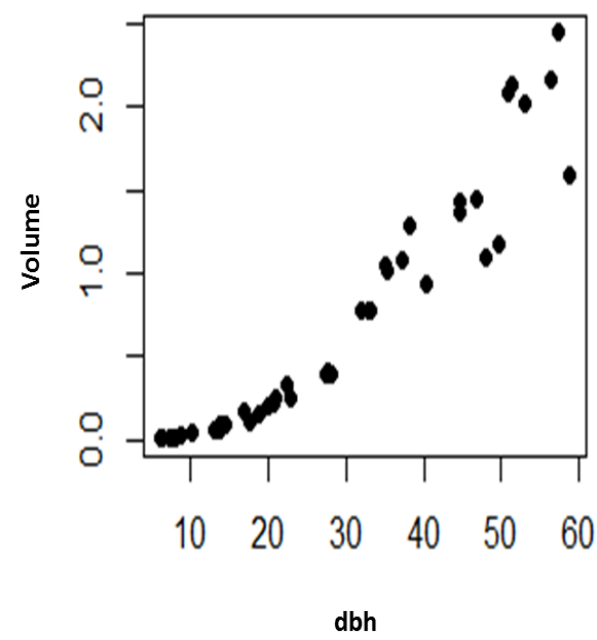

(a)

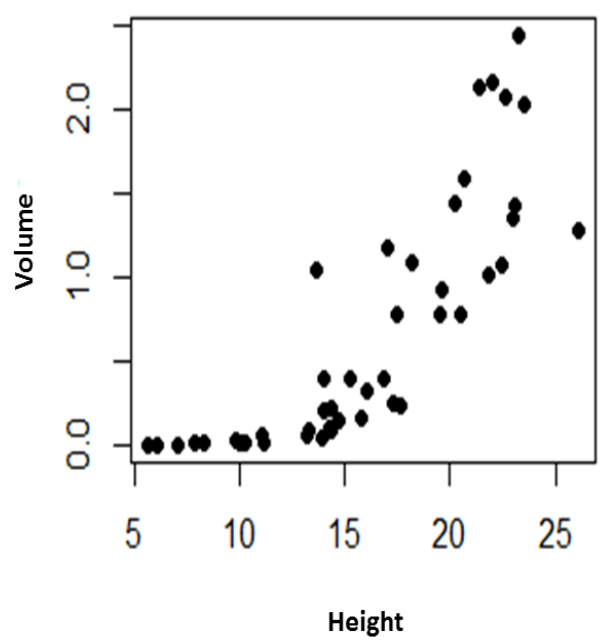

(b)

Figure 6: Scatter plot diagrams showing volume of tree in $\mathrm{m}^{3}$ against (a) diameter at breast height, dbh in $\mathrm{cm}$; and (b) height in $\mathrm{m}$. 
Several linear and non-linear volume models were reviewed for the study. The most common six volume equations were selected (Table 6). Among selected models, V1 was in the equation form having $\mathrm{dbh}$ as a single independent variable. The model $\mathrm{V} 2$ included $\mathrm{dbh}$ and squared value of dbh, while model $\mathrm{V} 3 \mathrm{had} \mathrm{dbh}$ and product of dbh and $\mathrm{H}$ (observed height in this case), as two independent variables. The last two models were slightly different as both of them had modelled height $\left(\mathrm{H}^{*}\right)$ from model $\mathrm{H} 2$, instead of observed height.

Table 6: Candidate volume models used for the study

\begin{tabular}{ll}
\hline \multicolumn{1}{c}{ Volume Models } & Model Designation \\
\hline$V=a+b \times(d b h)$ & $\mathrm{V} 1$ \\
$V=a+b \times(d b h)+c \times(d b h)^{2}$ & $\mathrm{~V} 2$ \\
$V=a+b \times(d b h)+c \times H$ & $\mathrm{~V} 3$ \\
$V=a+b \times(d b h)+c \times(d b h)^{2} \times H$ & $\mathrm{~V} 4$ \\
$V=a+b \times(d b h)+c \times H^{*}$ & $\mathrm{~V} 5$ \\
$V=a+b \times(d b h)+c \times(d b h)^{2} \times H^{*}$ & $\mathrm{~V} 6$
\end{tabular}

In six candidate volume models, $V$ is the total volume of the tree above stump height in cubic meter; $d b h$ is the diameter in centimeter at a breast height of 1.3 meter; $\ln (d b h)^{2}$ is natural logarithm of squared value of dbh; $H$ is the total observed height of the tree in meter; $H^{*}$ is the modelled height from selected best height-diameter model (model H2) in this study; and a and b are parameters to be estimated; and V1, V2 and V3, are candidate volume models.

Evaluation criteria as mentioned in Table 2 were tested for best fitted and validated volume equation. All parameter estimates of model V5 were only significant at 95\% confidence interval among six candidate models (Table 7). The $\mathrm{R}^{2}$ values for all models ranged from 0.949 to 0.993 . More than $94 \%$ of the variability in volumes were well described by all six models (adjusted $\mathrm{R}^{2}>0.949$ ). Models V2, V4, V5 and V6 showed somewhat similar and lower RMSE values. Biases for all models were lower than 0.0001 and were not considered for evaluation. The AIC values for all models were comparatively very low. The volume equations were further subjected to graphical analysis of residual plots (Figure 7) and scatter plots of predicted and observed volumes from given dbh (Figure 8).

The results from residual plot analysis showed models V4 and V5 performed well compared to other models. The analysis of observed and predicted volumes showed all models except V5 gave negative values of volume for some dbh. Volume, sometimes cannot be explained by simple models that only utilize dbh or height. It can be justified as some growth models are useful only for certain height and diameter levels and cannot perform well in absence of attributes like stand density and site quality, which significantly affect height-diameter relationships (Newton and Amponsah, 2007; Sharma and Parton, 2007; Sharma and Yin Zhang, 2004; Sharma, 2009; Temesgen and v. Gadow, 2004). The height for model V5 was calculated from best height-diameter model $\mathrm{H} 2$ from this study. Based on significance of parameter estimates as well as predicted values, model V5 was considered best model to estimate volume from given dbh and modelled height.

The first model V1 is the simplest one using only dbh as independent variable. It was considered as local volume equation of teak in that particular area. The comparison of models utilizing measured height (models V1, V2, V3 and V4) with models using modelled height (models V5 and V6) showed somewhat similar results in terms of $\mathrm{R}^{2}$ and adjusted $\mathrm{R}^{2}$. Using modelled height instead of actual observation can make measurement and prediction a lot easier. Forest landowners can easily apply any models with only one variable to measure. 
Table 7: Parameter estimates and validation criteria of the candidate models.

\begin{tabular}{|c|c|c|c|c|c|c|c|c|c|}
\hline Model & Parameter & $\begin{array}{l}\text { Parameter } \\
\text { estimate }\end{array}$ & $\begin{array}{l}\text { Standard } \\
\text { Error }\end{array}$ & $\mathrm{R}^{2}$ & Adj. $\mathrm{R}^{2}$ & RMSE & & Bias & AIC \\
\hline \multirow[t]{2}{*}{ V1 } & $a^{1}$ & -0.4720 & 0.068 & 0.949 & 0.944 & 0.20 & l & $<0.00$ & 1.16 \\
\hline & $b^{1}$ & 0.0414 & 0.002 & & & & & & \\
\hline \multirow[t]{3}{*}{$\mathrm{V} 2$} & $\mathrm{a}$ & -0.1192 & 0.104 & 0.992 & 0.990 & 0.08 & l & $<0.00$ & -20.68 \\
\hline & $\mathrm{b}$ & 0.0088 & 0.008 & & & & & & \\
\hline & $c^{1}$ & 0.0005 & 0.001 & & & & & & \\
\hline \multirow[t]{3}{*}{ V3 } & $a^{1}$ & -0.4544 & 0.133 & 0.959 & 0.951 & 0.18 & l & $<0.00$ & 0.25 \\
\hline & $b^{1}$ & -0.0420 & 0.004 & & & & & & \\
\hline & $\mathrm{c}$ & -0.0021 & 0.014 & & & & & & \\
\hline \multirow[t]{3}{*}{ V4 } & $\mathrm{a}$ & $-6.5 e-02$ & $7.4 \mathrm{e}-02$ & 0.994 & 0.993 & 0.07 & l & $<0.00$ & -24.85 \\
\hline & $\mathrm{b}$ & $8.1 \mathrm{e}-03$ & $4.9 \mathrm{e}-03$ & & & & & & \\
\hline & $c^{1}$ & $2.5 \mathrm{e}-05$ & $3.5 \mathrm{e}-06$ & & & & & & \\
\hline \multirow[t]{3}{*}{ V5 } & $\mathrm{a}^{1}$ & 0.3364 & 0.188 & 0.988 & 0.985 & 0.09 & l & $<0.00$ & -15.29 \\
\hline & $b^{1}$ & 0.0685 & 0.006 & & & & & & \\
\hline & $\mathrm{c}^{1}$ & -0.0970 & 0.022 & & & & & & \\
\hline \multirow[t]{3}{*}{ V6 } & $\mathrm{a}$ & $-1.6 e-01$ & $9.8 \mathrm{e}-02$ & 0.991 & 0.989 & 0.08 & 1 & $<0.00$ & -20.01 \\
\hline & $b^{1}$ & $1.6 \mathrm{e}-02$ & $6.6 \mathrm{e}-03$ & & & & & & \\
\hline & $\mathrm{c}^{1}$ & $1.9 \mathrm{e}-05$ & $4.7 \mathrm{e}-06$ & & & & & & \\
\hline
\end{tabular}

${ }^{1}$ Significant parameter values

\section{Limitations and scope of study}

The height-diameter equation and volume equations were developed for central lowland, Nepal. The application of these equations in other places should be performed cautiously. Less number of trees were felled for data analysis due to difficulties in destructive sampling. Variables like quadratic mean diameter, stand basal area or trees per hectare and form factor were not included during model construction, which could be considered for future studies. Such measures might possess complexity in data generation, model formulation and evaluation, but could yield stronger conclusion.

\section{Conclusions}

Teak trees from an important part in plantation forest of lowland, Nepal. Four height-diameter relationship equations and six tree volume estimation equations were fitted in observed data from the study site. The equation utilizing natural logarithm of dbh (diameter at breast height) was considered to 
be best model to predict Height in terms of fitness and validation characteristics. Similarly, the localized equation only using dbh to predict tree volume was selected for estimating volume of teak trees in Sagarnath area, whereas the equation using $\mathrm{dbh}$ and modeled height from the best selected height-diameter equation was considered to be applicable generic model for volume estimation. We believe that these models would be appropriate to be used in lowlands of Nepal and similar eco-region for teak species.

\section{Acknowledgments}

This project was supported by funding from NIFA -McIntire-Stennis project ME041621 and Sagarnath Forestry Development Project - Students research grant. We would like to express our gratitude to Bishnu Hari Wagle, Assistant Professor, Institute of Forestry, Tribhuvan University and Binod Kumar Singh, Assistant Forest Officer, Ilam, Nepal, for their valuable suggestions during the initial part of the study. Our appreciation goes to Raj Kumar Rimal and Elias Ayrey for their support in spatial data generation and model formulation respectively. We are very grateful to Dr. Krishna Poudel of Oregon State University for reviewing initial phase of this manuscript.

\section{References}

Basuki, T.M., van Laake, P.E., Skidmore, A.K., Hussin, Y.A., 2009. Allometric equations for estimating the above-ground biomass in tropical lowland Dipterocarp forests. For. Ecol. Manag. 257, 1684-1694. doi:10.1016/j.foreco.2009.01.027

Baty, F., Delignette-Muller, M., 2015. Tools for nonlinear regression analysis. R Package.

Bi, H., Hamilton, F., 1998. Stem volume equations for native tree species in southern New South Wales and Victoria. Aust. For. 61, 275-286. doi:10.1080/00049158.1998.10674752

Budhathoki, C.B., Lynch, T.B., Guldin, J.M., 2008. A mixed-effects model for the dbh-height relationship of shortleaf pine (Pinus echinata Mill.). South. J. Appl. For. 32, 5-11.

Calama, R., Montero, G., 2004. Interregional nonlinear height diameter model with random coefficients for stone pine in Spain. Can. J. For. Res. 34, 150-163.

Chapman, D.G., 1961. Statistical problems in dynamics of exploited fisheries populations, in: Proc. 4th Berkeley Symp. on Mathematics, Statistics and Probability. University of California Press Berkeley, pp. 153-168.

Chaturvedi, R.K., Raghubanshi, A.S., 2015. Allometric models for accurate estimation of aboveground biomass of Teak in tropical dry forests of India. For. Sci. 61, 938-949. doi:10.5849/forsci.14-190

Coble, D.W., Lee, Y.-J., 2011. A mixed-effects height-diameter model for individual loblolly and slash pine trees in East Texas. South. J. Appl. For. 35, 12-17.

Cordero, L.D.P., Kanninen, M., 2003. Provisional equations for estimating total and merchantable volume of Tectona grandis trees in Costa Rica. For. Trees Livelihoods 13, 345-359. doi:10.1080/14728028.2003.9752470

Die, A., Kitin, P., Kouame, F.N., Van den Bulcke, J., Van Acker, J., Beeckman, H., 2012. Fluctuations of cambial activity in relation to precipitation result in annual rings and intra-annual growth zones of xylem and phloem in teak (Tectona grandis) in Ivory Coast. Ann. Bot. 110, 861-873. doi:10.1093/aob/mcs145

FRA/DFRS, 2014. Terai Forests of Nepal (2010 - 2012). Forest Resource Assessment Nepal Project/Department of Forest Research and Survey.

Gautam, S.K., Thapa, H.B., 2007. Volume equation for Populus deltoides plantation in western Terai of Nepal. Banko Janakari 17, 70-73. 
Hansen, O.K., Changtragoon, S., Ponoy, B., Kjær, E.D., Minn, Y., Finkeldey, R., Nielsen, K.B., Graudal, L., 2015. Genetic resources of teak (Tectona grandis Linn. f.) — strong genetic structure among natural populations. Tree Genet. Genomes 11. doi:10.1007/s11295-014-0802-5

Husch, B., Beers, T.W., Kershaw Jr, J.A., 2002. Forest Mensuration, Fourth Edition. ed. John Wiley \& Sons.

Jayaraman, K., Zakrzewski, W.T., 2001. Practical approaches to calibrating height-diameter relationships for natural sugar maple stands in Ontario. For. Ecol. Manag. 148, 169-177.

Kaosa-ard, A., 1998. Overview of problems in teak plantation establishment, in: Teak for the Future Proceedings of the Second Regional Seminar on Teak. Presented at the Second Regional Seminar on Teak, Yangoon, Myanmar, pp. 49-59.

Kizha, A., Han, H.-S., 2016. Predicting aboveground biomass in second growth Coast Redwood: comparing localized with generic allometric models. Forests 7, 96. doi:10.3390/f7050096

Lappi, J., 1997. A longitudinal analysis of height/diameter curves. For. Sci. 43, 555-570.

Mandal, R.A., Yadav, B.K.V., Yadav, K.K., Dutta, I.C., Haque, S.M., 2013. Development of allometric equation for biomass estimation of eucalyptus camaldulensis: a study from Sagarnath Forest, Nepal. Int J Biodiv Ecosyst 1, 1-7.

Mugasha, W.A., Mwakalukwa, E.E., Luoga, E., Malimbwi, R.E., Zahabu, E., Silayo, D.S., Sola, G., Crete, P., Henry, M., Kashindye, A., 2016. Allometric Models for Estimating Tree Volume and Aboveground Biomass in Lowland Forests of Tanzania. Int. J. For. Res. 1-13. doi: $10.1155 / 2016 / 8076271$

Newton, P.F., Amponsah, I.G., 2007. Comparative evaluation of five height-diameter models developed for black spruce and jack pine stand-types in terms of goodness-of-fit, lack-of-fit and predictive ability. For. Ecol. Manag. 247, 149-166. doi:10.1016/j.foreco.2007.04.029

Parresol, B.R., 1999. Assessing tree and stand biomass: A review with examples and critical comparisons. For. Sci. 45, 573-593.

Peng, C., Zhang, L., Liu, J., 2001. Developing and validating nonlinear height-diameter models for major Tree species of Ontario's boreal forests. North. J. Appl. For. 18, 87-94.

Perez, D., 2008. Growth and volume equations developed from stem analysis for Tectona grandis in Costa Rica. J. Trop. For. Sci. 20, 66-75.

R Core Team, 2016. R: A language and environment for statistical computing. R Foundation for Statistical Computing, Vienna, Austria.

Richards, F.J., 1959. A flexible growth function for empirical use. J. Exp. Bot. 10, 290-301.

Sandeep, S., M. Sivaram, Henry, M., Birigazzi, L., 2014. Inventory of volume and biomass tree allometric equations for South Asia. UN-REDD Programme, India.

Sharma, M., Parton, J., 2007. Height-diameter equations for boreal tree species in Ontario using a mixed-effects modeling approach. For. Ecol. Manag. 249, 187-198. doi:10.1016/j.foreco.2007.05.006

Sharma, M., Yin Zhang, S., 2004. Height-Diameter Models Using Stand Characteristics for Pinus banksiana and Picea mariana. Scand. J. For. Res. 19, 442-451. doi:10.1080/02827580410030163 
Sharma, R.P., 2009. Modelling height-diameter relationship for Chir pine trees. Banko Janakari 19, 3-9. doi:10.3126/banko.v19i2.2978

Spruge, D.G., 1983. Correcting for bais in Log transformed allometric equations. Ecology 64, 209-210.

Temesgen, H., v. Gadow, K., 2004. Generalized height-diameter models—an application for major tree species in complex stands of interior British Columbia. Eur. J. For. Res. 123, 45-51. doi:10.1007/s10342-004-0020-z

Tewari, V.P., Mariswamy, K.M., 2013. Heartwood, sapwood and bark content of teak trees grown in Karnataka, India. J. For. Res. 24, 721-725. doi:10.1007/s11676-013-0410-5

Tewari, V.P., Mariswamy, K.M., Arunkumar, A.N., 2013. Total and merchantable volume equations for Tectona grandis Linn. f. plantations in Karnataka, India. J. Sustain. For. 32, 213-229. doi:10.1080/10549811.2013.762187

Thapa, H.B., Gautam, S.K., 2007. Growth performance of Tectona grandis Linn F. between two thinning operations at Shankarnagar, western Terai, Nepal. Banko Janakari 17, 11-17. doi:http://dx.doi.org/10.3126/banko.v17i2.2151

Thapa, H.B., Gautam, S.K., 2005. Growth performance of Tectona grandis in the western Terai of Nepal. Banko Janakari 15, 6-12. doi:http://dx.doi.org/10.3126/banko.v15i2.344

Trincado, G., Burkhart, H.E., 2006. A generalized approach for modeling and localizing stem profile curves. For. Sci. 52, 670-682.

Wagle, B.H., Sharma, R.P., 2012. Modelling individual tree basal area growth of Blue pine (Pinus wallichiana) for Mustang district in Nepal. For. Sci. Technol. 8, 21-27. doi:10.1080/21580103.2012.658236

Weiskittel, A.R., Hann, D.W., Kershaw Jr, J.A., Vanclay, J.K., 2011. Forest growth and yield modeling, First Edition. ed. John Wiley \& Sons.

Zahabu, E., Raphael, T., Chamshama, S.A.O., Iddi, S., Malimbwi, R.E., 2015. Effect of Spacing Regimes on Growth, Yield, and Wood Properties of Tectona grandis at Longuza Forest Plantation, Tanzania. Int. J. For. Res. 2015, 1-6. doi:10.1155/2015/469760

Zeide, B., 1993. Analysis of Growth Equations. For. Sci. 39, 594-616. 